\title{
Choice of Courses in Mathematics at Upper- Secondary School and Attitudes towards Mathematics among Business Students: The Case of Norway
}

\author{
Leiv Opstad \\ Norwegian University of Science and Technology \\ Trondheim \\ Torbjørn Årethun \\ Western Norway University of Applied Sciences \\ Sogndal
}

\begin{abstract}
This study will focus on students' attitude towards mathematics. A negative attitude might be one reason for choosing practical mathematics in upper secondary school. The sample includes 230 students from 3 business schools in Norway in their first half-year, when business mathematics was on their schedule. The data were collected through surveys. Then, using a factor analysis, a measurement instrument for 'attitude towards mathematics' was constructed. The chosen methods were the independent-samples $t$-test and a binary logistic regression. A substantial difference was found among the students depending on their choice of the mathematical level at uppersecondary school. The findings suggest that students with practical mathematics have substantially lower self-confidence, value and enjoyment in mathematics than those who chose the other levels of mathematics. Should Norwegian universities consider changing their requirements to a qualification level of skills within mathematics for degrees in economics and business administration? Changing the enrolment rules - requiring theoretical mathematics from uppersecondary school - would perhaps lead students with low selfconfidence and enjoyment in mathematics to choose courses that involve less use of mathematics.
\end{abstract}

Keywords: Attitudes; mathematics; business schools; binary logistic regression. 


\section{Introduction}

At Norwegian upper-secondary school, students can choose between three levels of mathematics. The first level is practical mathematics, and the two others are theoretical mathematics either within social sciences or within natural sciences. Several undergraduate courses in the field of business require theoretical skills in mathematics. Therefore, students who have chosen practical mathematics are falling behind in almost all courses at business school.

In Norway, admission to business schools is primarily based on the GPA (grade point average) from upper-secondary school independent of the kind of mathematics studied (practical or theoretical mathematics in either natural science or social science). The need for mathematics depends on the type of business course chosen. At the Norwegian business schools, there are some courses with little or no use of mathematics (like the introduction to organizational theory and business law) and others that involve some mathematics (courses in marketing and accounting). The moderate use of mathematics is necessary in macroeconomics, budgeting and introduction to business courses. Finally, there are courses with more intense use of mathematics (microeconomics and finance).

Many students are successful in passing mathematics at upper-secondary school, but they do not necessarily perform well in business studies. Various undergraduate courses in the business area require theoretical skills in mathematics. Students with a lack of knowledge of mathematics are at risk of underperformance. Therefore, students who have chosen practical mathematics are falling behind in almost all courses at business schools (Opstad, 2018). The difference is largest in quantitative courses. As a result, students who have taken practical mathematics courses are not necessarily ready for studying at business schools. Remediation of this gap will take time and incur costs. Many students will never catch up. Why are so many students taking practical mathematics? To improve the success rate within business courses, we need a better picture of who these students are.

This study will focus on students' attitude towards mathematics. A negative attitude towards mathematics might be a reason for choosing practical mathematics. One can avoid studying more mathematics than necessary, even though a higher level of mathematics is a strong predictor of success in business studies. The level of preparedness gained through upper-secondary school is a critical factor for performance in business schools. Do students choose practical mathematics due to lower values of attitudes towards mathematics? Many students made the choice before they had a clear idea about their further studies.

Using factor analysis, a measurement instrument for attitude towards mathematics will be constructed in this paper.

\section{Literature Review}

Many studies have examined attitudes towards mathematics using different versions of factors and instruments. Fennema and Sherman (1976) wrote a classical article presenting nine scales: (1) Attitude towards Success in Mathematics, (2) Male Domain, (3) Mother Scale, (4) Father Scale, (5) Teacher 
Scale, (6) Confidence, (7) Anxiety, (8) Motivation and (9) Usefulness. Other researchers have made modifications to the Fennema-Sherman scales. Adediwura (2011) focused on confidence, anxiety, motivation and usefulness. Tapia and Marsh (2004) constructed new instruments to measure attitudes towards mathematics, including confidence, anxiety, value, enjoyment, motivation and parent/teacher expectation. They constructed a factor analysis using four scales: (1) Self-Confidence, (2) Value, (3) Enjoyment and (4) Motivation. They dropped the parent/teacher factor, since it did not seem to have a substantial impact. Many studies have used this four-scale model (Guy et al., 2015; Huang \& Lin, 2015; Majeed et al., 2013).

Some studies have limited the research to three indicators by dropping motivation (Adelson \& McCoach, 2011; Kiwanuka et al., 2017). High levels of anxiety related to mathematics might have a negative impact on students' choices. Students with high mathematics anxiety perform worse in mathematics courses (Luttenberger et al.,2018; Sheffield \& Hunt, 2006). Students' attitude towards mathematics is a key factor for learning mathematics and has a positive impact on their mathematical achievement (Benken et al., 2015; Groen et al., 2015; Higgins et al., 2017). Many will try to avoid mathematics even if it is a very important subject for their future career (Anderson, 2007; Mutawah \& Masooma, 2015).

Mathematics self-concept has a positive effect on achievement, but an increased level of enjoyment in mathematics does not have any direct impact on performance (Pinxten et al., 2014). On the other hand, García et al. (2016) and Mazana et al. (2019) find a positive relationship between enjoyment and mathematics achievement. The question remains of whether making mathematics more enjoyable will have an influence on the result. Students who fail in mathematics report a lower level of self-confidence and motivation. Furthermore, those who have a negative attitude towards mathematics obtain low grades in their final exam (Núñez-Peña et al., 2013; Christopher, 2018).

Research on the gender gap in regard to attitudes towards mathematics is mixed. Odell and Schumacher (1998) observed that males had a more positive attitude towards mathematics than females at a business college. Hyde et al. (1990) found the gender difference in mathematics to be moderate, but their results indicated that males are more confident than females. Other studies have found no significant gender differences (Köğce et al., 2009; Mohd et al., 2011; Yeo et al., 2015). In other fields like students' reading achievement the research shows a gender gap in favour of girls (Osman et al. 2016).

This study sought to understand the impact of business students' attitude towards mathematics on their selection of mathematics options at uppersecondary school. The use of mathematics in business schools depends on the kind of course, but one cannot complete the programme without using mathematics. Is there a link between the attitudes towards mathematics and the choice of courses in mathematics? Is there a gender gap? This paper does not emphasis on the factors that develop students' attitude towards mathematics. 


\section{The Structure of Upper-Secondary School Mathematics}

In Norway, studying mathematics is compulsory for the two first years of upper-secondary school. In the second year, students can choose between:

1. Practical mathematics (P maths)

The students learn about useful functions for making mathematical models of practical relationships. The focus is on functions in practice to describe and analyse situations from daily life and working life.

2. Mathematics for business and social science (S1 maths)

The students deal with the language of symbols in mathematics, involving symbols and the active use of formulae. The subjects include algebra, the use of functions and the analysis of graphs and deal with exponential functions and regression analyses. The students learn about calculation and solving equations of the first and second degree. They also become familiar with the binominal as well as the hypergeometric distribution.

3. Mathematics for natural science (N1 maths)

This includes the calculation and analysis of figures in the plane. A main subject is geometry, including the use of vectors and coordinates to convert geometrical problems into algebra. The students also deal with the development of formal logical arguments in a geometrical context. (In Norway, this course is called R1 maths).

In the last year of upper-secondary school, mathematics is voluntary. However, students who have taken S1 or N1 mathematics can choose to continue with mathematics in the last year but only in the same field. With natural science mathematics, one can study more advanced mathematics in those topics (N2 mathematics). With S1 mathematics from the second year, one can decide to specialize in the same area by taking S2 mathematics.

\section{Data, Methodology and Result}

This section presents the data collected for the study and the sampling procedures applied. The methods of analyses and the results are provided in the final part of the section.

\section{Study Sample}

In accordance with the research objective, data were gathered by surveying students. The sample includes 230 students from 3 business schools in Norway in their first half-year, when business mathematics was on the schedule. This is a compulsory course to ensure that students have the background needed for business courses. The majority of the participants in the sample attended the Norwegian University of Science and Technology (NTNU) Business School. The students responded to a designed questionnaire during a compulsory course in 
the first semester. Most of them chose to answer the questionnaire, but it did not catch up with students who were absent from the course that day. This explains why the response rate is around 60 per cent.

Table 1. Compulsory mathematics courses: Second year at upper-secondary school

\begin{tabular}{|l|l|l|r|c|}
\hline Course & Males & Females & All & Percentage \\
\hline P & 37 & 30 & 67 & 29.1 \\
\hline S1 & 56 & 49 & 105 & 45.7 \\
\hline N1 & 36 & 22 & 58 & 25.2 \\
\hline All & $129(55.9 \%)$ & $101(44.1 \%)$ & 230 & 100.0 \\
\hline
\end{tabular}

Table 2.Voluntary mathematics courses: Third year at upper-secondary school

\begin{tabular}{|l|c|l|c|c|}
\hline Course & Males & Females & All & Percentage \\
\hline S2 & 44 & 38 & 82 & 35.6 \\
\hline N2 & 23 & 14 & 37 & 16.1 \\
\hline Non-mathematical course & 62 & 49 & 111 & 48.3 \\
\hline & 129 & 101 & 230 & 100.0 \\
\hline
\end{tabular}

The majority of the students are males. The most popular course is mathematics for business and social science. This course provides the skills that are most relevant to business studies. This is the best choice for students who plan to attend business schools. About half of the students did not take any mathematical course in their last year at upper-secondary school. The boys found the most theoretical course (N2) to be more attractive than the girls.

The students were non-randomly allocated. We have not evaluated the representativeness of the final sample by comparing the average student characteristics for the final sample with the characteristics of all the enrolled students, but this has been undertaken in a previous similar study (Bonesrønning \& Opstad, 2015). There were slightly more girls than boys, and the average student in the sample had a slightly higher GPA than the average student. The reason is that higher percentages of male students and of students with lower achievement were absent from the lectures. The difference was small. We assume that the situation is the same for this sample as well, but data are not available for testing this.

Students' attitudes towards mathematics can be measured by using the Attitudes Toward Mathematics Inventory (ATMI) (Tapia and Marsh, 2004). Sundre et al. (2012) used this method for Norwegian students without performing any factor analysis. Since it is not clear how well these questions fit Norwegian students, we decided to conduct a factor analysis. It is not necessarily the case that a research instrument that has been proven to be reliable and effective in an American educational context is valid for Norwegian conditions. A test using the dataset in this study applying the same classification confirmed this assumption.

Like many other studies (Adelson \& McCoach, 2011; Kiwanuka et al., 2017), we limit the analysis to only three factors. According to Lim and Chapman (2013), attitudes towards mathematics can be categorized into three sub-constructs: (i) enjoyment of mathematics; (ii) self-confidence in mathematics; and (iii) value of 
mathematics. They removed the motivation subscale since there was a high correlation between enjoyment and motivation $(r=0.96)$. This shorter ATMI did not have an impact on the property of the instrument.

The criteria for choosing items for the construction of the factor analysis were (Adelson \& McCoach, 2011):

(a) the coefficient was at least 0.4 ;

(b) the pattern coefficient for non-relevant factors was less than 0.3;

(c) the pattern coefficient for non-relevant factors was 0.2 or less than the value of the relevant factor;

(d) the Cronbach's alpha was above 0.70 .

Table 3 presents the result from the factor analysis using the different components. A 7-point Likert scale was selected, on which strongly disagree $=1$ and strongly agree $=7$. This choice is not obvious, but a 7-point scale might perform better than a 5-point scale (Joshi et al., 2015). Following the definition, we constructed six items for each to reflect the three categories.

Table 3. Results of the factor analysis

\begin{tabular}{|c|c|c|c|c|}
\hline & No. & $\begin{array}{l}\text { Item } \\
\text { (7-point Likert scale) }\end{array}$ & $\begin{array}{l}\text { Factor } \\
\text { loading }\end{array}$ & $\begin{array}{l}\text { Cronbach's } \\
\text { alpha }\end{array}$ \\
\hline \multirow[t]{6}{*}{$\begin{array}{l}\text { Self- } \\
\text { confidence }\end{array}$} & 1 & $\begin{array}{l}\text { I have a lot of self-confidence when it comes to } \\
\text { mathematics }\end{array}$ & 0.847 & \multirow{6}{*}{0.89} \\
\hline & 2 & I learn mathematics easily & 0.831 & \\
\hline & 3 & I believe I am good at solving mathematics problems & 0.816 & \\
\hline & 4 & $\begin{array}{l}\text { I am able to solve mathematics problems without } \\
\text { too much difficulty }\end{array}$ & 0.804 & \\
\hline & 5 & Mathematics does not scare me at all & 0.676 & \\
\hline & 6 & $\begin{array}{l}\text { I expect to do fairly well in any mathematics class } \\
\text { that I take }\end{array}$ & 0.445 & \\
\hline \multirow[t]{6}{*}{ Value } & 1 & $\begin{array}{l}\text { Mathematics is a very worthwhile and necessary } \\
\text { subject }\end{array}$ & 0.901 & \multirow{6}{*}{0.85} \\
\hline & 2 & $\begin{array}{l}\text { Mathematics is one of the most important subjects } \\
\text { for people to study }\end{array}$ & 0.763 & \\
\hline & 3 & Mathematics is important in everyday life & 0.672 & \\
\hline & 4 & $\begin{array}{l}\text { A strong mathematics background could help me in } \\
\text { my professional life }\end{array}$ & 0.546 & \\
\hline & 5 & I think studying advanced mathematics is useful & 0.446 & \\
\hline & 6 & $\begin{array}{l}\text { I can think of many ways in which I use } \\
\text { mathematics outside school }\end{array}$ & 0.442 & \\
\hline \multirow[t]{6}{*}{ Enjoyment } & 1 & Mathematics is a very interesting subject & 0.785 & \multirow{6}{*}{0.80} \\
\hline & 2 & $\begin{array}{l}\text { I am happier in a mathematics class than in any } \\
\text { other class }\end{array}$ & 0.675 & \\
\hline & 3 & $\begin{array}{l}\text { I would prefer to do an assignment in mathematics } \\
\text { than to write an essay }\end{array}$ & 0.500 & \\
\hline & 4 & I like to solve new problems in mathematics & 0.482 & \\
\hline & 5 & $\begin{array}{l}\text { I gain great satisfaction from solving a mathematics } \\
\text { problem }\end{array}$ & 0.449 & \\
\hline & 6 & $\begin{array}{l}\text { I am willing to take more than the required amount } \\
\text { of mathematics }\end{array}$ & 0.435 & \\
\hline
\end{tabular}


Table 4 gives a thorough definition of each of the three separate categories.

Table 4. Categories

\begin{tabular}{|l|l|}
\hline Category & Description \\
\hline Self-confidence & $\begin{array}{l}\text { To measure students confidence and self- } \\
\text { concept of their performance in } \\
\text { mathematics. It measures whether or not } \\
\text { students believe that they have enough } \\
\text { ability to succeed in mathematics. }\end{array}$ \\
\hline Value of mathematics & $\begin{array}{l}\text { To measure students beliefs in the } \\
\text { usefulness relevance and worth of } \\
\text { mathematics in their life now and in the } \\
\text { future. }\end{array}$ \\
\hline Enjoyment of mathematics & $\begin{array}{l}\text { To measure the degree to which students } \\
\text { enjoy working with mathematics. }\end{array}$ \\
\hline
\end{tabular}

The self-confidence category contains items measuring students' certainty in the subject. It depends on their ability and expectation of achieving good grades. Following the definition, we constructed six items for each to reflect the three categories.

Table 5. Mean value for different mathematical backgrounds in upper-secondary school (the items were measured using a 7-point Likert scale (1 being 'strongly disagree' and 7 'strongly agree')

\begin{tabular}{|l|l|l|l|l|l|l|l|}
\hline Dimension & $\mathbf{P}$ & S1 & N1 & S2 & N2 & ALL & St. dev. \\
\hline $\begin{array}{l}\text { Self- } \\
\text { confidence }\end{array}$ & 3.59 & 4.37 & 4.80 & 4.59 & 5.13 & 4.26 & 1.19 \\
\hline $\begin{array}{l}\text { Value of } \\
\text { mathematics }\end{array}$ & 4.49 & 5.00 & 5.28 & 5.03 & 5.46 & 4.97 & 1.08 \\
\hline $\begin{array}{l}\text { Enjoyment of } \\
\text { mathematics }\end{array}$ & 3.99 & 4.14 & 4.49 & 4.29 & 4.79 & 4.41 & 1.08 \\
\hline $\mathrm{N}$ & $(67)$ & $(105)$ & $(58)$ & $(88)$ & $(37)$ & $(229)$ & \\
\hline
\end{tabular}

Table 5 presents the mean score on each of the three dimensions for students opting for different levels of mathematics in upper secondary school.

Table 6a. Independent samples t-test (two-tailed): S1 compared with P

\begin{tabular}{|l|l|l|}
\hline Dimension & $\begin{array}{l}\text { Mean } \\
\text { difference }\end{array}$ & $\begin{array}{l}\text { T-value (assuming unequal } \\
\text { variances) }\end{array}$ \\
\hline Self-confidence & 0.784 & $4.58\left(^{* * *}\right)$ \\
\hline Value of mathematics & 0.513 & $\left.2.950{ }^{* * *}\right)$ \\
\hline Enjoyment of mathematics & 0.154 & 1.00 \\
\hline & \multicolumn{2}{|l|}{} \\
\hline Notes: ${ }^{*},{ }^{* *}$ and ${ }^{* * *}$ denote significance at the $10 \%, 5 \%$ and $1 \%$ level, respectively. \\
\hline
\end{tabular}


Table 6b. Independent samples t-test (two-tailed): N1 compared with $P$

\begin{tabular}{|l|l|l|}
\hline Dimension & $\begin{array}{l}\text { Mean } \\
\text { Difference }\end{array}$ & $\begin{array}{l}\text { T-value (assuming unequal } \\
\text { variances) }\end{array}$ \\
\hline Self-confidence & 1.22 & $6.43\left(^{* * *}\right)$ \\
\hline Value of mathematics & 0.791 & $4.38\left(^{* * *}\right)$ \\
\hline Enjoyment of mathematics & 0.49 & $2.47\left({ }^{* *}\right)$ \\
\hline \multicolumn{2}{|l|}{ Notes: ${ }^{* * *}$ and ${ }^{* * *}$ denote significance at the $10 \%, 5 \%$ and $1 \%$ level, respectively. } \\
\hline
\end{tabular}

Table 6 presents the result of pairwise comparisons of the mean using an independent sample t-test. The mean values are between 3.5 and 5.5 for all three dimensions and highest for the value of mathematics (Table 5). The score is lower among the P students than among the $\mathrm{S}$ and $\mathrm{N}$ students. The three scales for measuring attitudes towards mathematics reveal minor scores. P students have less self-confidence and find mathematics to be less useful than students with other mathematical backgrounds. The independent samples t-test (Table 6) was used for analysing the difference between practical $(\mathrm{P})$ and theoretical mathematics (S1 or N1). The impact is strongly significant for all three categories. The diversity in the average score of enjoyment is smaller. The effect is still significant for $\mathrm{P}$ students in relation to $\mathrm{N}$ students but not if one links those to students of $S$ mathematics. The students who selected natural science mathematics at upper-secondary school tend to have high scores in selfconfidence and the value of mathematics.

The score for attitude towards mathematics increases overall for the students who chose mathematics in their last year at upper-secondary school. Table 7 shows the gender difference. There is only a moderate difference except for selfconfidence, for which the male students have a higher value than the female students.

Table 7. The gender result: Mean value

\begin{tabular}{|l|l|l|l|l|}
\hline Dimension & Female & Male & ALL & St. d. \\
\hline $\begin{array}{l}\text { Self- } \\
\text { confidence }\end{array}$ & 3.95 & 4.38 & 4.18 & 1.22 \\
\hline $\begin{array}{l}\text { Value of } \\
\text { mathematics }\end{array}$ & 4.77 & 5.94 & 4.86 & 1.08 \\
\hline $\begin{array}{l}\text { Enjoyment of } \\
\text { mathematics }\end{array}$ & 4.23 & 4.13 & 4.17 & 1.09 \\
\hline $\mathrm{N}$ & 123 & 149 & 272 & \\
\hline
\end{tabular}

Pairwise comparison of means has some limitation. It does not take into count how different factors affect the result simultaneously. To further investigate the impact on the choice of mathematics at secondary upper school, we will carry out another statistical analysis. This research utilized a binary logistic regression model to examine the influence of attitudes towards mathematics on the selection of mathematical courses at upper-secondary school. Does students' attitude matter for the choice of a mathematical pathway? The independent variables are gender, self-confidence, value and enjoyment of mathematics. In the model, $\mathrm{a}_{0}$ is a constant, e denotes the stochastic error and $a_{i}$ are regression coefficients. The form of the chosen linear binary production model is: 
Where:

$$
Y i=a_{0}+a_{1} X_{1}+a_{2} X_{2}+a_{3} X_{3}+a_{4} X_{4}+e
$$

Yi: Mathematical course at upper-secondary school (0: P, 1: either S1 or N1)

$\mathrm{a}_{0}$ : Constant

$\mathrm{X}_{1}$ : Gender (F: 1, M:O).

$\mathrm{X}_{2}$ : Mean value of self-confidence using a 7-point Likert score.

$X_{3}$ : Mean value of the use of mathematics using a 7-point Likert score.

$\mathrm{X}_{4}$ : Mean value of enjoyment of mathematics using a 7-point Likert score.

Binary logistic regression is useful when the dependent variable has only two values. We limit the analysis to compare P with S1 and N1 mathematics. The independent variables selected are gender and attitude towards mathematics. Using this model, one can identify more clearly and simultaneously the relationship between attitudes, gender and choice of mathematical course. Table 8 presents the result.

Table 8a. Result of the binary logistic regression. Dependent variable: S1 or P mathematics

\begin{tabular}{|l|l|l|l|}
\hline $\begin{array}{l}\text { Independent } \\
\text { variable }\end{array}$ & $\begin{array}{l}\text { Coef. B } \\
\text { (std. err.) }\end{array}$ & WALD & Exp(B) \\
\hline Constant & $\begin{array}{l}-2.55 \\
(0.94)\end{array}$ & $7.32\left(^{* * *}\right)$ & 0.078 \\
\hline Gender & $\begin{array}{l}0.49 \\
(0.36)\end{array}$ & 1.88 & 1.64 \\
\hline $\begin{array}{l}\text { Self-confidence in } \\
\text { mathematics }\end{array}$ & $\begin{array}{l}0.748 \\
(0.20)\end{array}$ & $15.34\left(^{* * *}\right)$ & 2.19 \\
\hline $\begin{array}{l}\text { Value of } \\
\text { mathematics }\end{array}$ & $\begin{array}{l}0.41 \\
(0.24)\end{array}$ & $3.94\left(^{* *}\right)$ & 1.51 \\
\hline $\begin{array}{l}\text { Enjoyment of } \\
\text { mathematics }\end{array}$ & -0.56 & $5.67\left(^{* *}\right)$ & 0.57 \\
\hline
\end{tabular}

$\mathrm{R}^{2}$ (Nagelkerke) $=0.20, \mathrm{~N}=171$

Notes: ${ }^{*},{ }^{* *}$ and ${ }^{* * *}$ denote significance at the $10 \%, 5 \%$ and $1 \%$ level, respectively.

Table $8 b$. Result of the binary logistic regression. Dependent variable: N1 or P mathematics

\begin{tabular}{|l|l|l|l|}
\hline $\begin{array}{l}\text { Independent } \\
\text { variable }\end{array}$ & $\begin{array}{l}\text { Coef. B } \\
\text { (std. err.) }\end{array}$ & WALD & Exp(B) \\
\hline Constant & $\begin{array}{l}-5,22 \\
(1.26)\end{array}$ & $17.17\left(^{* * *}\right)$ & 0.005 \\
\hline Gender & $\begin{array}{l}0.21 \\
(0.45)\end{array}$ & 0.211 & 1.23 \\
\hline $\begin{array}{l}\text { Self-confidence in } \\
\text { mathematics }\end{array}$ & $\begin{array}{l}1.13 \\
(0.28)\end{array}$ & $16.70\left(^{* * *}\right)$ & 3.10 \\
\hline $\begin{array}{l}\text { Value of } \\
\text { mathematics }\end{array}$ & $\begin{array}{l}0.42 \\
(0.26)\end{array}$ & 2.54 & 1.52 \\
\hline $\begin{array}{l}\text { Enjoyment of } \\
\text { mathematics }\end{array}$ & $\begin{array}{l}-0.43 \\
(0.25)\end{array}$ & $2.82\left(^{*}\right)$ & 0.66 \\
\hline
\end{tabular}

$\mathrm{R}^{2}$ (Nagelkerke) $=0.36, \mathrm{~N}=124$

Notes: ${ }^{*},{ }^{* *}$ and ${ }^{* * *}$ denote significance at the $10 \%, 5 \%$ and $1 \%$ level, respectively. 
Students' attitude towards mathematics has an influence on their choice of mathematical programmes at upper-secondary school. Students with a lower degree of self-confidence tend to prefer P mathematics. The effect is strong and highly significant. The impact of the value of mathematics is less substantial and is only significant for $\mathrm{S}$ compared with $\mathrm{P}$ mathematics. Notice that the enjoyment of mathematics is also significant but with negative coefficients, and it is strongest for $\mathrm{S}$ and $\mathrm{P}$ mathematics. In this model, the enjoyment of mathematics is positive correlated with the choice of P mathematics. It should also be noted that there is no significant gender impact.

The SPSS does not produce collinearity diagnostics in logistic regression. However, one can obtain the VIF value by running a linear regression. This gave VIF scores between 1.1 and 1.8. The multicollinearity is therefore not considered as a problem for the regression analysis performed. Table 9 shows the correlation matrix among the independent variables.

Table 9. Correlation matrix

\begin{tabular}{l|r|r|r|r|r}
\hline & Constant & Gender & Enjoyment & $\begin{array}{c}\text { Self- } \\
\text { confidence }\end{array}$ & \multicolumn{1}{c}{ Value } \\
\hline Constant & 1.000 & -.275 & -.175 & -.325 & -.456 \\
\hline Gender & -.275 & 1.000 & -.183 & .286 & .046 \\
\hline Enjoyment & -.175 & -.183 & 1.000 & -.401 & -.460 \\
\hline Self-confidence & -.325 & .286 & -.401 & 1.000 & -.144 \\
\hline Value & -.456 & .046 & -.460 & -.144 & 1.000 \\
\hline
\end{tabular}

\section{Discussion}

Male students have been reported to participate more in advanced courses in mathematics and have higher self-confidence than female students (Sax et al., 2015). Our data may indicate that this is the case. However, the binary regression model does not show any significant gender effect among the students from the three business schools in Norway. Even though boys can have more selfconfidence in mathematics, the gender variance in attitudes is not universal (Reilly et al., 2019).

The finding suggests that $\mathrm{P}$ students have substantially lower self-confidence than other students. Those with low self-confidence tend to choose the easiest pathway. Therefore, many students have no more mathematics than is necessary for attending business schools. Students with high self-confidence prefer theoretical mathematics. There is a strong correlation between self-confidence and choice of courses in mathematics.

The result from the regression model shows a significant positive connection between the value of mathematics and the choice of $\mathrm{S}$ mathematics students but not that of $\mathrm{N}$ mathematics students. The reason might be that students with $\mathrm{S}$ mathematics can more easily see the connection between this kind of mathematics and the need for mathematics in business courses. There is a great overlap between $S$ mathematics and business schools' obligatory mathematics.

International studies have indicated that students with science mathematics 
believe in and have a great interest in mathematics (Musu-Gillette et al., 2015). Ercikan et al. (2005) and Shih et al. (2019) suggested that students' attitude towards mathematics is a very strong predictor of their participation in advanced mathematics courses. Attending an advanced mathematics course is linked to choosing a university major in mathematics or a field of study that requires a high level of mathematical ability (Nagy et al., 2006). Those students are less likely to choose a field of study related to moderate use of mathematics. If we follow this line of reasoning, we would not expect so many students with $\mathrm{N} 1$ and N2 mathematics at business schools. Some of their skills in mathematics from upper-secondary school are not relevant in business courses, like geometry and vector analysis. Their ability is not adapted in the same way as for those with $S$ mathematics. This can explain why the binary regression model for students with natural science mathematics (Table $8 \mathrm{~b}$ ) does not have a significant effect to the same degree as for those students with business and social science mathematics (Table 8a).

It is not easy to explain why the coefficient is negative and significant between those with $S$ mathematics and the enjoyment of mathematics. The same outcome emerges for students with $\mathrm{N}$ mathematics, but it is not so strong. The students with $\mathrm{P}$ mathematics tend to have the highest enjoyment in mathematics in this study, if we take other factors into account. A partial comparison does not show the same result (see Table 5). One reason for this finding could be that many students select theoretical mathematics because it is useful. As Johnston (1994) pointed out, one has to choose the kind of mathematics that one needs even if one does not like it. Since it is an advantage to have a background in theoretical mathematics when attending business courses and it is valuable, students end up picking those courses. Students with high self-confidence in mathematics can probably handle those courses more easily. The enjoyment factor might be of less importance. Undoubtedly, many students with S mathematics have chosen this path due to their interest in business courses and economics. This kind of mathematics is an advantage compared with $\mathrm{P}$ and probably also with $\mathrm{N}$ mathematics for achievement in most business courses.

Since the portfolio of business courses is heterogeneous, students facing difficulties in some courses may enjoy benefits in others. This depends on their personal characteristics and background. Mathematical ability is still one of the most important factors for success in quantitative courses (Opstad, 2018), and most students probably know this. Even with little confidence in mathematics, one realizes the usefulness of mathematics. This can explain why

the difference in the mean scores for the value of mathematic is rather small compared with that for self-confidence among the three units of mathematics pathways in upper-secondary school (see Table 5).

Students with practical mathematics have on average lower self-confidence than other groups. Some students prefer $\mathrm{P}$ mathematics because they find mathematics difficult and lack self-confidence. With low interest and low selfconfidence in mathematics, they prefer non- challenging mathematics courses (Nagy et al., 2006) and have a higher likelihood of making that choice. Lim and Chapman (2015) found a strong correlation between self-confidence and achievement. With negative attitudes towards mathematics, it is almost 
impossible to achieve success in mathematics (Yaratan \& Kasapoğlu, 2012). Low self-confidence is associated with low performance in mathematics.

Therefore, those students tend to perform poorly in business mathematics and quantitative business courses. Their advantages are in non-quantitative courses and studies that do not use mathematics, since they discourage the use of mathematical tools. Many fail to take exams in business mathematics. They struggle to achieve a grade, and many of them just give up and drop out of the programme. Attending business school, they realize that they need knowledge in mathematics that is hard to achieve (Opstad \& Årethun, 2019).

However, it is not a homogeneous group. Figure 1 illustrates this. A substantial proportion of the students with the $\mathrm{P}$ level in mathematics have high selfconfidence in mathematics. Despite the fact that they can probably solve mathematical problems easily, they have chosen P mathematics.

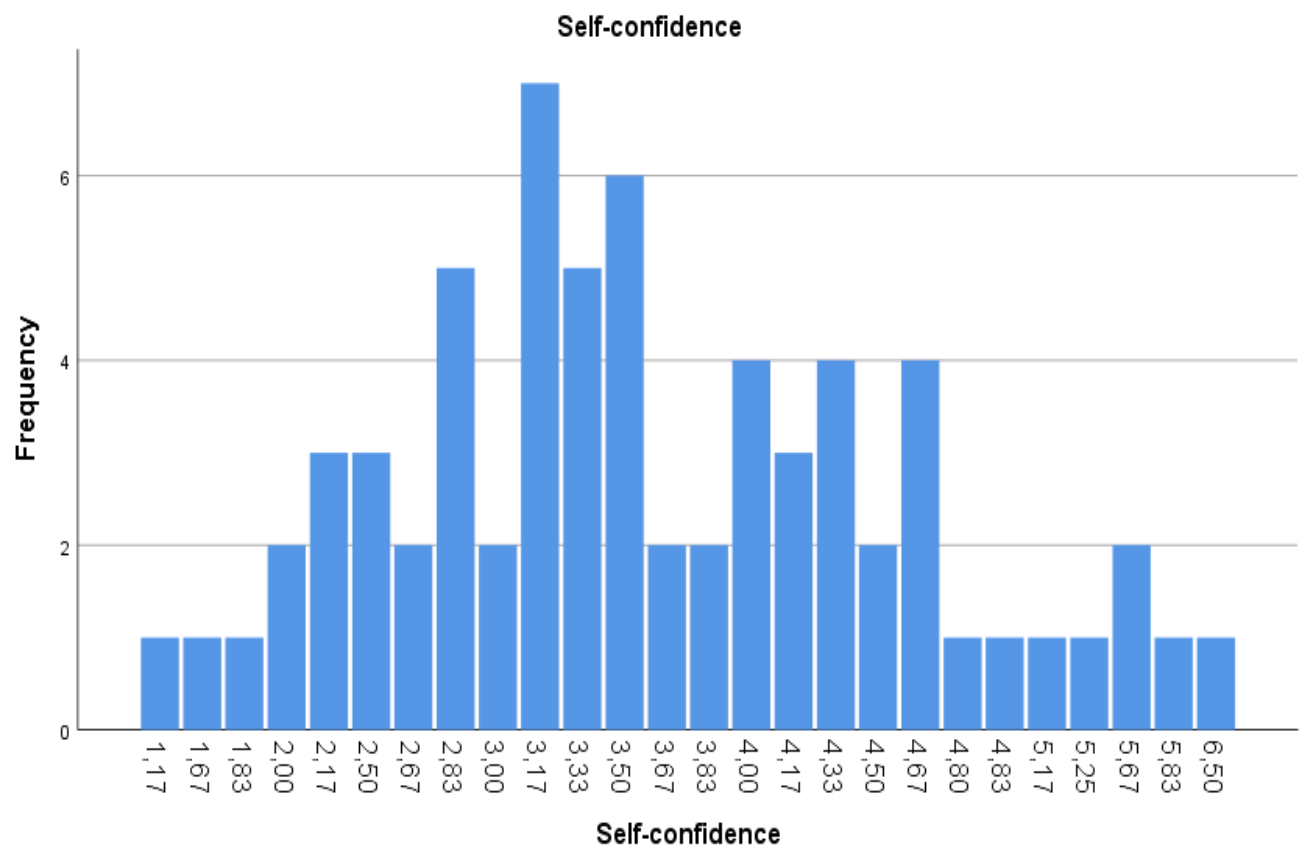

Figure 1. Self-confidence among students with practical mathematics.

There could be various reasons for this, for example planning logistics, other interests and priorities (Opstad \& Årethun, 2019). Students might also be tempted to perceive a lower level of mathematics to raise their university entry rank due to the entry rules to business studies (Sikora and Pitt, 2018). With hard work and effort in business mathematics, many of them with practical mathematics manage to catch up and achieve good performance in quantitative courses as well. Those students perform well in business mathematics (Opstad, 2017). A high score in self-confidence in mathematics correlates with success in business mathematics, and the opposite is the case for a low level of selfconfidence. Ercikan et al. (2005) showed that students' mathematics confidence is the strongest predictor of achievement. The score of self-confidence is therefore an indicator of performance in business mathematics and quantitative business courses. Assuming that this reasoning applies to students with practical mathematics, this means that $\mathrm{P}$ students with a high score in self-confidence will 
perform well in quantitative courses.

Few business schools in Norway require a prerequisite level of skills in mathematics for admission to the programme. In most Norwegian business schools, admittance is based on the GPA scores from upper-secondary school. There is no prerequisite level of skills in mathematics. Students with low self-confidence find mathematics difficult to learn. Due to a lack of selfconfidence, they tend to seek the easiest way to meet the requirement in mathematics. The selection will be made during the compulsory introduction course in mathematics. All students see the usefulness of mathematics, but, due to a lack of confidence and ability, they find business studies challenging (Opstad \& Årethun, 2019). Changing the enrolment rules and requiring at least S mathematics from upper-secondary school would probably result in many students with low self-confidence in mathematics would choose studies with less use of mathematics than business courses. The selection would be made before attending business schools. In this way, there would be a lower drop-out rate and better use of resources. A change of state requirements in mathematics will have an impact on students' choice (Federman et al., 2007).

\section{Limitation}

The causal effect is not obvious (Núñez-Peña et al., 2013). Attitudes towards mathematics have an impact on performance, but the selection of the mathematical level might influence attitudes. The data are from the first year at business school. The choice of mathematics at upper-secondary school is made at least 2 years before attending higher education. Students' attitudes might change during those years. Their selection of their mathematical pathway at upper-secondary school might also influence their attitude. Students choose their mathematics level based on their prior performance in mathematics and their attitude (Sikora \& Pitt, 2018). Furthermore, being a business student can have an impact on attitudes towards mathematics, including the experience with the compulsory course in business mathematics. Even if one dislikes mathematics, one can see the value in business courses. The students are more mature and know more about the role of mathematics in business courses. This can change their attitudes, for instance regarding the value of mathematics, depending on their choices and experience (Musu-Gillette et al., 2015). Nevertheless, it is of interest to study the link between the attitudes towards mathematics in the first years at business school and the choice of mathematical courses at upper-secondary school.

The value of the R square is rather low. Obviously, other factors have an effect on students' choices. Despite these limitations, this study provides some important material about the reasons for students' preferences for mathematics courses at upper-secondary school.

\section{Conclusion}

Attitudes towards mathematics vary among students at Norwegian business schools. These attitudes influence their choice of mathematical programmes at upper-secondary school. Mathematics matters for those kinds of studies. 
Therefore, students see the usefulness of learning mathematics. Students with practical mathematics at upper-secondary school have substantially lower selfconfidence than other students. This might be a reason for their decision to avoid theoretical mathematics. By requiring theoretical mathematics as a condition for enrolment at business school, the students given an entry ticket will be less heterogeneous. This might improve the selection of students attending business schools.

For further research, it would be interesting to compare the career of former business students who chose practical and theoretical mathematics in upper secondary school, respectively.

\section{References}

Adediwura, A. A. (2011). The development and confirmatory factor analysis of a scale for the measurement of gifted students attitude towards mathematics. World Journal of Education, 1(1), 52-62. doi:10.1080/19477503.2019.1582960

Adelson, J. L. \& McCoach, D. B. (2011). Development and psychometric properties of the math and me survey: Measuring third through sixth graders' attitudes toward mathematics. Measurement and Evaluation in Counseling and Development, 44(4), 225-247. doi:10.1177/0748175611418522

Anderson, V. (2007). An online survey to assess student anxiety and attitude response to six different mathematical problems. Launceston College and University of Tasmania. Mathematics: Essential Research, Essential Practice, 1, 93-102.

Benken, B. M., Ramirez, J., Li, X. \& Wetendorf, S. (2015). Developmental mathematics success: Impact of students' knowledge and attitudes. Journal of Developmental Education, 14-31.doi:10.1080/19477503.2019.1582960

Bonesrønning, H. \& Opstad, L. (2015). Can student effort be manipulated? Does it matter? Applied Economics, 47(1)5, 1511-1524. doi:10.1080/00036846.2014.9979

Christopher, B. A. (2018). The Relationship Between Calibration, Mindset, Mathematics Anxiety and Achievement in Pre-Service Elementary Teachers.

Ercikan, L., McCreith, T. \& Lapointe, V. (2005). Factors associated with mathematics achievement and participation in advanced mathematics courses: An examination of gender differences from an international perspective. School Science and Mathematics, 105(1), 5-14. doi:10.1111/j.1949-8594.2005.tb18031.x

Federman, M. (2007). State graduation requirements, high school course taking, and choosing a technical college major. BE Journal of Economic Analysis \& Policy, 7(1). doi:10.2202/1935-1682.1521

Fennema, E. \& Sherman, J. (1976). Fennema-Sherman mathematics attitudes scales: Instrument designed to measure attitudes toward mathematics, toward the learning of mathematics by females and males. Journal for Research in Mathematics Education, 7, 324-326. doi:10.2307/748467

García, T., Rodriguez, C., Betts, L., Areces, D. \& González-Castro, P. (2016). How affective-motivational variables and approaches to learning predict mathematics achievement in upper elementary levels. Learning and Individual Differences, 49, 25-31. doi:10.1016/j.lindif.2016.05.021

Groen, L., Coupland, M., Langtry, T., Memar, J., Moore, B., \& Stanley, J. (2015). The mathematics problem and mastery learning for first-year, undergraduate STEM students. International Journal of Learning, Teaching and Educational Research, 11(1). 
Guy, G. M., Cornick, J. \& Beckford, I. (2015). More than math: On the affective domain in developmental mathematics. International Journal for the Scholarship of Teaching and Learning, 9(2), 7.doi:10.20429/ijsotl.2015.090207 Press.

Higgins, K., Huscroft-D' Angelo, J. \& Crawford, L. (2017). Effects of technology in mathematics on achievement, motivation, and attitude: A meta-analysis. Journal of Educational Computing Research, 57(2). doi:10.1177/0735633117748416

Huang, Y.-C. \& Lin, S.-H. (2015). Development and validation of an inventory for measuring student attitudes toward calculus. Measurement and Evaluation in Counseling and Development, 48(2), 109-123. doi:10.1177/0748175614563314

Hyde, J. S., Fennema, E., Ryan, M., Frost, L. A. \& Hopp, C. (1990). Gender comparisons of mathematics attitudes and affect: A meta-analysis. Psychology of Women, 14(3), 299-324. doi:10.1111/j.1471-6402.1990.tb00022.x

Johnston, S. (1994). Choosing mathematics: 'You need it even if you don't want to do it'. Australian Journal of Education, 38, 233-249. doi:10.1177/000494419403800304

Joshi, A., Kale, S., Chandel, S. \& Pal, D. K. (2015). Likert scale: Explored and explained. British Journal of Applied Science \& Technology, 7(4), 396. doi:10.9734/bjast/2015/14975

Kiwanuka, H. N., Van Damme, J., Van Den Noortgate, W., Anumendem, D. N., Vanlaar, G., Reynolds, C. \& Speranza, N. (2017). How do student and classroom characteristics affect attitude toward mathematics? A multivariate multilevel analysis. School Effectiveness and School Improvement, 28(1), 1-21. doi:10.1080/09243453.2016.1201123

Köğce, D., Yildiz, C., Aydin, M. \& Altindag, R. (2009). Examining elementary school students' attitudes towards mathematics in terms of some variables. Procedia Social and Behavioral Sciences, 1, 291-295. doi:10.1016/j.sbspro.2009.01.053.01.05301.053

Lim, S. Y. \& Chapman, E. (2013). Development of a short form of the attitudes toward mathematics inventory. Educational Studies in Mathematics: An International Journal, 82, 145-164. doi:10.1007/s10649-012-9414-x

Lim, S. Y. \& Chapman, E. (2015). Identifying affective domains that correlate and predict mathematics performance in high-performing students in Singapore. Educational Psychology, 35(6), 747-764. doi:10.1080/01443410.2013.860221

Luttenberger, S., Wimmer, S., \& Paechter, M. (2018). Spotlight on math anxiety. Psychology research and behavior management, 11, 311. doi:10.2147/PRBM.S141421

Majeed, A. A., Gusti Ngurah Darmawan, I. \& Lynch, P. (2013). A confirmatory factor analysis of attitudes toward mathematics inventory (ATMI). Available at: digital.library.adelaide.edu.au

Mazana, M. Y., Montero, C. S., \& Oyelere, S. S. (2019, May). Information and Communication Technology in Mathematics Education-Integration Readiness in Tanzania Higher Education Institutions. In International Conference on Social Implications of Computers in Developing Countries (pp. 409-420). Springer, Cham.

Mohd, N., Mahmood, T. F. P. T., \& Ismail, M. N. (2011). Factors that influence students in mathematics achievement. International Journal of Academic Research, 3(3), 49-54.

Musu-Gillette, L. E., Wigfield, A., Harring, J. R. \& Eccles, J. S. (2015). Trajectories of change in students' self-concepts of ability and values in math and college major choice. Educational Research and Evaluation, 21(4), 343-370. doi:10.1080/13803611.2015.1057161

Mutawah, A. \& Masooma, A. (2015). The influence of mathematics anxiety in middle and high school students math achievement. International Education Studies, 8(11), 239-252. doi:10.5539/ies.v8n11p239 
Nagy, G., Trautwein, U., Baumert, J., Köller, O. \& Garrett, J. (2006). Gender and course selection in upper secondary education: Effects of academic self-concept and intrinsic value. Educational Research and Evaluation, 12(4), 323-345. doi:10.1080/13803610600765687

Núñez-Peña, M. I., Suarez-Pellicioni, M. \& Bono, R. (2013). Effects of math anxiety on student success in higher education. International Journal of Education Research, 58, 36-43. doi:10.1016/j.ijer.2012.12.004

Odell, P. M. \& Schumacher, P. (1998). Attitudes toward mathematics and predictors of college mathematics grades: Gender differences in a 4-year business college. Journal of Education for Business, 74(1), 34-38. doi:10.1080/08832329809601658

Opstad, L. (2017). Matematikkens betydning for suksess ved økonomisk-administrative studier. Bred og spiss! NTNU Handelshøyskolen 50 år: En vitenskapelig jubileumsantologi (in Norwegian).

Opstad, L. (2018). Success in business studies and mathematical background: The case of Norway. Journal of Applied Research in Higher Education, 10(3), 399-408. Available from: https://doi.org/10.1108/JARHE-11-2017-0136

Opstad, L. \& Årethun, T. (2019). Val av matematikkretning i den vidaregåande skulen. Unpublished paper, Department of Economics, NTNU, Norway (in Norwegian).

Osman, M. E. T., Al Khamisi, H., Al Barwani, T., \& Al Mekhlafi, A. (2016). EFL reading achievement: Impact of gender and self-efficacy beliefs. International Journal of Learning, Teaching and Educational Research, 15(3).

Pinxten, M., Marsh, H. W., De Fraine, B., Van Den Noortgate, W. \& Van Damme, J. (2014). Enjoying mathematics or feeling competent in mathematics? Reciprocal effects on mathematics achievement and perceived math effort expenditure. British Journal of Educational Psychology, 84(1), 152-174. doi:10.1111/bjep.12028

Reilly, D., Neumann, D. L. \& Andrews, G. (2019). Investigating gender differences in mathematics and science: Results from the 2011 Trends in Mathematics and Science Survey. Research in Science Education, 49(1), 25-50. doi:10.1007/s11165017-9630-6

Sax, L. J., Kanny, M. A., Riggers-Piehl, T. A., Whang, H. \& Paulson, L. N. (2015). ‘But I'm not good at math': The changing salience of mathematical self-concept in shaping women's and men's STEM aspirations. Research in Higher Education, 56(8), 813-842. doi:10.1007/s11162-015-9375-x

Sheffield, D. \& Hunt, T. (2006). How does anxiety influence maths performance and what can we do about it? Retrieved from http://journals.heacademy.ac.uk/, doi10.11120/msor.2006.06040019

Shih, J., Ing, M., Phelan, J., Brown, R., \& Maiorca, C. (2019). The Influence of Students' Self-Perceptions and Mathematics Experiences on Learning More Mathematics in the Future. Investigations in Mathematics Learning, 11(3), 220-229. doi:10.1080/19477503.2019.1582960

Sikora, J. \& Pitt, D. G. (2018). Does advanced mathematics help students enter university more than basic mathematics? Gender and returns to year 12 mathematics in Australia. Mathematics Education Research Journal, 1-22. doi:10.1007/s13394-0180249-3

Sundre, D., Barry, C., Gynnild, V. \& Tangen Ostgard, E. (2012). Motivation for achievement and attitudes toward mathematics instruction in a required calculus course at the Norwegian University of Science and Technology. Numeracy, 5(1), 4. doi:10.5038/1936-4660.5.1.4

Tapia, M. \& Marsh II, G. E. (2004). An instrument to measure mathematics attitudes. Academic Exchange Quarterly, Summer, p. 16+. Academic OneFile. Available from: 
https://link.galegroup.com/apps/doc/A121714083/AONE?u=googlescholar\& sid=AONE\&xid=abd79c72. Accessed 18 February 2019.

Yaratan, H. \& Kasapoğlu, L. (2012). Eighth grade students' attitude, anxiety, and achievement pertaining to mathematics lessons. Procedia - Social and Behavioral Sciences, 46, 162-171. doi:10.1016/j.sbspro.2012.05.087

Yeo, W. L., Tan, C. K. \& Lew, S. L. (2015). Mathematics anxiety among male and female students. World Academy of Science, Engineering and Technology, International Journal of Social, Behavioral, Educational, Economic, Business and Industrial Engineering, 9(8), 2830-2835. doi:10.1016/j.sbspro.2010.12.066 